\title{
Self-Care Behaviors and Health Indicators in Adults with Type 2 Diabetes ${ }^{1}$
}

\author{
Lidia Guadalupe Compeán Ortiz² \\ Esther Carlota Gallegos Cabriales ${ }^{3}$ \\ José Gerardo González González ${ }^{4}$ \\ Marco Vinicio Gómez Meza ${ }^{5}$
}

This descriptive correlational study aimed to analyze self-care behaviors and their relationship with health indicators represented by glycemic control, lipid profile, Body Mass Index [BMI], waist circumference and body fat percentage in a sample of 98 adults with type 2 diabetes in an area of Nuevo Leon, Mexico (August 2005/May 2006). The results showed a low self-care behaviors index $(\tilde{X}=36.94, S D=15.14)$. A significant relationship was found between self-care behaviors and glycosilated hemoglobin [HbA1c] $\left(r_{s}=-.379\right.$, $p<.001)$, triglycerides $\left(r_{s}=-.208, \mathrm{p}=.040\right)$, BMI $\left(r_{s}=-.248, \mathrm{p}=.014\right)$ and body fat percentage $\left(r_{s}=-.221, \mathrm{p}=.029\right)$. Multivariate analysis revealed the influence of self-care behaviors on HbA1c, BMI and body fat percentage with explained variances of 9 to $41 \%(p<.05)$. From all self-care dimensions, diet was the most predictive for health indicators, moderated by gender and understanding of diabetes contents $(p<.05)$.

Descriptors: Self-Care; Health Status Indicators; Diabetes Mellitus, Type 2.

\footnotetext{
${ }^{1}$ Paper extracted from Doctoral Dissertation "Autocuidado en adultos con diabetes tipo 2: Influencia de la memoria y el aprendizaje", Facultad de Enfermería de la Universidad Autónoma de Nuevo León, Monterrey México. Supported by Programa de Mejoramiento del Profesorado (PROMEP-SEP), Universidad Autónoma de Tamaulipas, México.

2 Ph.D. in Nursing, Research Professor, Facultad de Enfermería, Campus Tampico, Universidad Autónoma de Tamaulipas, México. E-mail: Icompean@uat.edu.mx.

${ }^{3}$ Ph.D. in Nursing Philosofy, Research Professor, Facultad de Enfermería, Universidad Autónoma de Nuevo León, México. E-mail: egallego@fe.uanl.mx.

${ }^{4}$ Endocrinologist, Ph.D. in Medicine, Hospital Universitario "Dr. José Eleuterio González", Universidad Autónoma de Nuevo León, México. E-mail: gergonz@hotmail.com.

5 Research Professor, Facultad de Economía Centro de Estadística, Universidad Autónoma de Nuevo León, México. E-mail: marcogvmeza@hotmail.com.
}

Corresponding Author:

Lidia Guadalupe Compeán Ortiz

Universidad Autónoma de Tamaulipas, Facultad de Enfermería

Campus Tampico

Avenida Universidad, Boulevard López Mateos S/N

89140 Tampico, Tamaulipas, México

E-mail: Icompean@uat.edu.mx 


\section{Condutas de autocuidado e indicadores de saúde em adultos com diabetes tipo 2}

Estudo descritivo correlacional que teve como objetivo analisar as condutas de autocuidado e a sua relação com indicadores de saúde, representados pelo controle glicêmico, perfil de lipídios, índice de massa corpórea (IMC), circunferência da cintura e porcentagem de gordura corporal, em amostra aleatória de 98 adultos com diabetes tipo 2, de uma zona conturbada em Nuevo León, México (agosto 2005/maio 2006). Os resultados mostraram índice de autocuidado baixo $(\tilde{X}=36,94, d p=15,14)$. Encontrou-se correlação significativa entre o autocuidado e a hemoglobina glicolisada (HbA1c) $\left(r_{s}=\right.$ -0,379, $p<0,001)$, triglicerídeos $\left(r_{s}=-0,208, p=0,040\right)$, IMC $\left(r_{s}=-0,248, p=0,014\right)$ e gordura corporal $\left(r_{s}=-0,221, p=0,029\right)$. A análise multivariada revelou influência do autocuidado em HbA1c, IMC e gordura corporal com variâncias explicadas de 9 a $41 \%$ $(p<0,05)$. Das dimensões do autocuidado, a dieta foi o principal fator de predição moderado pelo gênero e a compreensão dos conceitos sobre o diabetes $(p<0,05)$.

Descritores: Autocuidado; Indicadores Basicos de Saúde; Diabetes Mellitus Tipo 2.

\section{Conductas de autocuidado e indicadores de salud en adultos con diabetes tipo 2}

Se trata de un estudio descriptivo y correlacional que tuvo como objetivo analizar las conductas de autocuidado y su relación con indicadores de salud, representados por el control de la glucemia, perfil de lípidos, IMC, circunferencia de cintura y porcentaje de grasa corporal, en una muestra aleatoria de 98 adultos con diabetes tipo 2 de un zona periférica de la ciudad de Nuevo León, en México; los datos fueron recolectados entre agosto del 2005 y mayo del 2006. Los resultados mostraron un índice de autocuidado bajo (promedio $=36,94$ y desvío estándar $=15,14$ ). Se encontró correlación significativa entre el autocuidado y la HbA1c $\left(r_{s}=-0,379, p<0,001\right)$, triglicéridos $\left(r_{s}=-0,208\right.$, $p=0,040), \operatorname{IMC}\left(r_{s}=-0,248, \mathrm{p}=0,014\right)$ y grasa corporal $\left(r_{s}=-0,221, p=0,029\right)$. El análisis multivariado reveló influencia del autocuidado en HbA1c, IMC y grasa corporal con varianzas explicadas de $9 \%$ a $41 \%(p<0,05)$. De los factores del autocuidado, la dieta fue el principal factor de predicción moderado por el género y la comprensión de los aspectos de la diabetes $(p<0,05)$.

Descriptores: Autocuidado; Indicadores de Salud; Diabetes Mellitus Tipo 2.

\section{Introduction}

Diabetes mellitus is one of the most common chronic diseases nowadays and is considered a public health problem around the world. The total number of people with this syndrome reached 171 million in the year 2000 and is projected to reach 366 million by $2030^{(1)}$. In Mexico, a growing trend has been observed in prevalence rates, as its increase has outranked the transmissible diseases that ranked first in the mortality lists until more than three decades ago. Diabetes is the first cause of general mortality, the second cause of healthy life years lost in women and the sixth in men, and the disease consuming the highest amount of public resources. Today, more than five million adults over 20 years of age suffer from the syndrome in Mexico(2).

The most frequent form is type 2 diabetes (DMT2), with about $90-95 \%$ of cases, and its start at an early age exposes patients to a longer period of possible hyperglycemia and, thus, a greater risk of chronic complications. In the long term, hyperglycemia can produce retinopathies, nephropathies, neuropathies, cardiopathies; therefore, glycemic control is the main treatment goal and it includes fasting blood glucose, glycosilated hemoglobin (HbA1c), cholesterol and triglycerides ${ }^{(3)}$. 
Among these indicators, $\mathrm{HbA} 1 \mathrm{c}$ is the best indicator for the risk of future complications, a situation some authors have evidenced, with percentages below 7\% showing an association with less microvascular complications ${ }^{(4)}$. Blood glucose permits measuring the level at the moment the sample is collected, but by itself cannot guarantee adequate glycemic control, mainly if measured only from time to time. Indicators like cholesterol, triglycerides and lipoproteins are important in diabetes patients due to their association with a greater risk of cardiovascular diseases and, together with obesity and arterial hypertension, they can favor the development of insulin resistance and metabolic syndrome(5).

To achieve adequate glycemic control, patients should maintain a correct balance between different elements of a comprehensive treatment, such as diet, exercise, medication, glucose monitoring and permanent education. Self-care (SC) behaviors become essential for DMT2 patients to maintain and improve their health, but represent a challenge for patients as well as health professionals.

Different studies have highlighted the importance of self-care ${ }^{(6-8)}$, but diabetes prevalence levels continue to increase and this is reflected in statistics. In Mexico, although prevalence levels are higher among patients aged 60 years or older, in an important proportion of cases, the disease starts before the age of 40 , with considerable implications: longer disease time exposes to longer hyper glycemia periods, favoring the start or exacerbation of complications, which affect patients' quality of life and can lead to death. With a view to supporting care delivery for patients with diabetes mellitus and identifying some related factors, this research was carried out. Self-care behaviors were defined as the activities diabetes patients perform to take care of their health in terms of diet, exercise, glucose monitoring and medication intake.

\section{Aims}

In view of the above, the aims of this research were: to analyze self-care behaviors (diet, exercise, monitoring and medication) and their relation with health indicators like HbA1c, cholesterol, triglycerides, BMI, waist circumference and body fat percentage; to describe the influence of age, schooling, gender and education/previous understanding about diabetes on self-care and health indicators and, to determine differences in self-care behaviors according to gender, age, schooling and occupation.

\section{Methods}

A descriptive correlational study was carried out between August 2005 and May 2006. The population comprised type 2 diabetes mellitus patients in a primary health care clinic in the suburbs of Nuevo León, México. Simple random sampling was used. A sample of 98 participants was calculated, using $n$-Query advisor 4.0 software, with a $95 \%$ confidence level and power of .80. Inclusion criteria were: having type 2 diabetes mellitus, age between 30 and 55 years and knowing how to read and write. Exclusion criteria were: presence of cognitive deterioration, psychiatric disorders and severe depression.

Patients were randomly selected from the general patient list and contacted by phone or at home to schedule a first interview at the clinic, where the inclusion and exclusion criteria were assessed. For this purpose, a data form was used, including: a) sociodemographic data and b) clinical antecedents in line with patient files.

Cognitive deterioration was discarded through the Mini-Mental State Examination, which assesses the cognitive state in areas such as time and place, attention, concentration, memory and language. The global score ranges from 0 to 30 . The cut-off point used for inclusion was 23 or more. Severe depression was discarded using Beck's Depression Inventory, with 21 items. Maximum score on each item is 3 points. In the total score, 9 or less is considered normal, 10-20 as light depression, 21-30 as moderate depression and $31-63$ as severe depression. Participants with severe depression were excluded and forwarded to the Psychology Department of the Primary Health Care Clinic. Both instruments have been validated for the Mexican population ${ }^{(9-10)}$. Patients who did not correspond to the profile received educative orientations and were thanked for their participation. Patients with the adequate profile were formally invited through the informed consent form.

Anthropometric measures like height and weight were taken, as well as body fat percentage and waist circumference, using a stadimeter, Tanita scales and a fiberglass measuring tape, respectively. The World Health Organization criteria for overweight and obesity were used $^{(11)}$. The Self-Care Activities Questionnaire ${ }^{(12)}$, which is based on typical elements of diabetes treatment (diet, exercise, glycemic monitoring and medication), with 12 questions about activities carried out seven days before the interview. The Spanish version was submitted to face and content validation by professionals and validated through a pilot study. Net 
instrument scores were transformed into scores from 0 to 100 , with higher scores reflecting better self-care. Moreover, the education and understanding dimensions of the Diabetes Profile Questionnaire(13) ${ }^{(13}$ were used, with 16 questions related to past diabetes education and its understanding. Higher rates reflect better education/ understanding. This instrument was also submitted to pertinent evaluation.

$\mathrm{HbA1c}$, cholesterol and triglycerides were determined. For $\mathrm{HbA1c}<7.0 \%$ was considered an acceptable cut-off point ${ }^{(14)}$. For the fat profile, total cholesterol levels $<200 \mathrm{mg} / \mathrm{dl}$ and triglycerides $<150$ $\mathrm{mg} / \mathrm{dl}$ were considered excellent ${ }^{(15)}$. This research complied with the Rules of the Mexican General Health Law for research ${ }^{(16)}$ and was authorized by the Research Ethics Commission of the Primary Health Care Clinic and the School of Nursing at Universidad Autónoma de Nuevo León.

Data were processed and analyzed in SPSS version 15, using descriptive and inferential statistics. Frequencies, proportions, central tendency measures were applied. Before inferential analysis, KolmogorovSmirnov's normality test was applied and, based on the result, the researchers decided to use non-parametric statistics. For the first aim, Spearman's correlation test was used while, for the second, multivariate analysis was adjusted and, for the third, Mann Whitney's U-test and Kruskal-Wallis test were used for the third aim.

\section{Results}

$74.5 \%$ of participants were women. The average age of the sample was 47 years $(S D=5.41)$ and average education 7.9 years $(S D=3.38)$. The most prevalent occupation was housewife (48\%), followed by employee in private companies (24.5\%) and in the informal sector (10.2\%). The average result for previous diabetes education was $84.95(S D=19.90)$ and for understanding $60.73(S D=18.46)$. The global self-care score was low $(X=36.94, S D=15.14)$. The results per dimension are shown in Table 1.

Table 1 - Self-care behaviors per dimension

\begin{tabular}{lccccc}
\hline & $\mathrm{X}$ & $\boldsymbol{S D}$ & $\boldsymbol{M d n}$ & Minimum & Maximum \\
\hline Diet & 48.72 & 16.87 & 50 & 5 & 80 \\
Exercise & 21.84 & 24.92 & 16 & 0 & 100 \\
Medication & 73.16 & 31.35 & 66 & 0 & 100 \\
Monitoring & 9.77 & 21.44 & 0 & 0 & 100 \\
\hline
\end{tabular}

Source: Self-Care Activities Questionnaire $n=98$

More than $60 \%$ of participants showed levels outside the normal range for all health indicators except for cholesterol. Table 2 shows frequencies and percentages per classification.

Table 2 - Health Indicators

\begin{tabular}{lcc}
\hline & $\boldsymbol{f}$ & $\%$ \\
\hline HbA1c & & \\
$\quad$ Adequate & 26 & 26.5 \\
$\quad$ Inadequate & 72 & 73.5 \\
Cholesterol & & \\
$\quad$ Normal & 46 & 46.9 \\
Regular & 36 & 36.7 \\
Bad & 16 & 16.3 \\
Triglycerides & & \\
$\quad$ Normal & 32 & 32.7 \\
Regular & 24 & 24.5 \\
$\quad$ Bad & 38 & 38.8 \\
$\quad$ Very bad & 4 & 4.1 \\
BMI & & \\
$\quad$ Normal & 7 & 7.1 \\
Overweight & 36 & 36.7 \\
Obesity & 55 & 56.1 \\
Waist Circumference & & \\
No risk & 13 & 13.3 \\
Increased risk & 20 & 20.4 \\
Highly increased risk & 65 & 66.3 \\
\hline
\end{tabular}

Source: Laboratory and anthropometric measurements $\mathrm{n}=98$

To achieve the first aim, Spearman correlations were calculated between global self-care and health indicators. Better self-care corresponded to lower $\mathrm{HbA} 1 \mathrm{c}$ levels $\left(r_{s}=-.379, p<.001\right)$, which means better glycemic control. Likewise, a significant negative relation was observed between self-care and triglyceride levels $\left(r_{s}=-.208, p=.040\right)$, self-care and body fat $\left(r_{s}=-.221\right.$, $p=.029)$, and self-care and BMI $\left(r_{s}=-.248, p=.014\right)$. This analysis was performed per self-care dimension (see Table 3), in which the relation between the diet dimension and various health indicators stands out.

Table 3 - Correlations between self-care dimensions and health indicators

\begin{tabular}{lccccccc}
\hline & HbA1c & $\begin{array}{c}\text { Body } \\
\text { fat }\end{array}$ & Cholesterol & Triglycerides & BMI & Waist \\
\hline Diet & $-.339^{* *}$ & $-.213^{*}$ & -.046 & -.024 & $-.238^{*}$ & $-.232^{*}$ \\
Exercise & -.161 & -.178 & -.173 & $-.211^{*}$ & -.159 & -.029 \\
Medication & -.185 & .075 & $-.243^{*}$ & -.085 & -.046 & .034 \\
Monitoring & -.083 & -.057 & -.002 & -.050 & -.017 & -.161 \\
\hline$* * p<.001, * p<.05$. & & & &
\end{tabular}

With respect to the second objective, a multivariate general linear model was adjusted, including health indicators (HbA1c, cholesterol, triglycerides, waist, body fat and BMI) as outcome variables and general self-care as the independent variable, moderated 
by age, schooling, gender and diabetes education/ understanding. Using the backward method, the most predictive model revealed that only gender $(p<.05)$ moderated the relation between self-care and health indicators. Inside the model (intra-subject analysis), significant influence $(p<.05)$ was observed for HbA1c, BMI and body fat only, with explained variances of 9 to $41 \%$. Another multivariate model was adjusted, including the four dimensions of self-care as independent variables (diet, exercise, monitoring and medication) and health indicators as dependent variables. Through the backward method, the most predictive model only included the diet dimension as predictive of health indicators $(p<.05)$, moderated by gender $(p<.001)$ and previous understanding about diabetes $(p=.04)$. Inside the model, the highest explained variance was for the body fat indicator $\left(R^{2}=.43\right)$.

With regard to the third aim, which was to determine self-care differences according to gender, age, schooling and occupation, significant differences were found for exercise and according to gender only $(U=552, p=.003)$. Men practiced more exercise $(M d n=27.78)$ than women $(M d n=11.11)$.

\section{Discussion}

With regard to self-care, the general score obtained in this population was low, in line with other studies ${ }^{(6-7)}$, but other authors have reported higher average self-care scores $^{(17)}$. One possible explanation for this difference could derive from the study samples and the different methods in each of the studies. A better action level was observed for medication when compared with diet, exercise and monitoring. This finding is in line with what other authors have reported about medication consumption skills ${ }^{(18)}$.

The high level found in one self-care dimension only is consistent with literature, which suggests that it tends to decrease according to the complexity of the therapeutic regimen. Activities like diet are harder to maintain because they can be influenced by a complex interaction of processes, including conditioning, customs and culture(19), while patients face less difficulties for medication intake. The low levels of self-care found in this study for diet and exercise are in line with the high prevalence of obesity and overweight, which exceeds the most recent estimations reported in Mexico(20) but is consistent with other authors ${ }^{(8)}$.

One of the main results of this study was the relation between self-care and glycemic control (represented by $\mathrm{HbA1c}$ ), observed in the correlations and later in the gender-moderated multivariate analysis. Despite a modest relation, this finding is in line with other studies $^{(17,21)}$ that reported that better self-care predicted better glycemic control (low HbA1c). It should also be acknowledged that these authors do not mention that this relationship was moderated by gender.

Among the self-care dimensions, the strongest relation was found between diet and health indicators (moderated by gender and previous understanding of diabetes). This finding is very relevant, as it coincides with the emphasis put on multidisciplinary interventions ${ }^{(14)}$, based on educative contents that are mainly focused on lifestyles, food and exercise to achieve better glycemic control. Education is a key process to achieve the modification of unhealthy lifestyles and better disease control(22-25).

With regard to self-care according to gender, men showed higher exercise levels than women. One explanation for this finding in this sample could be their type of occupation. While most women worked as housewives, most men were workers or employees in private companies, implying greater activity.

\section{Conclusions}

In this research, low general self-care scores were found for adults with type 2 diabetes mellitus with regard to diet, exercise and glucose monitoring, as well as poor glycemic control and high prevalence of obesity/overweight. For better general self-care behaviors, better health indicators were found, such as better glycosilated hemoglobin, low BMI and less body fat, the latter influenced by gender. As for selfcare dimensions, for more diet actions, a lower body fat percentage was observed, influenced by gender and previous understanding of diabetes contents.

This study reveals the need to reconsider the teaching contents and strategies health professionals use for diabetes patient education. Cognitive-educative multidisciplinary interventions directed at adults can favor the individual and responsible acquisition of healthy behaviors, mainly regarding diet, exercise and self-monitoring, which affect glycemic control, so as to decrease the risk of complications and improve quality of life. Different social, cognitive and cultural factors need to be explored to guarantee learning that makes diabetes patients take effective actions. Specifically nurses, in the role of health promoters, can facilitate the acquisition of these skills and contribute to the maintenance and improvement of individual health. 


\section{References}

1. Wild S, Roglic G, Green A, Sicree R, King H. Global prevalence of diabetes. Estimates for the year 2000 and projections for 2030. Diabetes Care. 2004;27(5):1047-53.

2. Secretaría de Salud (MX). Programa Nacional de Salud 20072012. México (DF): Secretaría de Salud; 2007.

3. American Diabetes Association. Standards of medical care in diabetes. Diabetes Care 2005. January; 8(1 Suppl):4-36.

4. United Kingdom Prospective Diabetes Study Group. Intensive blood glucose control with sulphonylureas or insulin compared with conventional treatment and risk of complications in patients with type 2 diabetes: UKPDS 33. Lancet. 1998;352(12):837-53.

5. American Diabetes Association. The metabolic syndrome: Time for a critical appraisal. Diabetes Care. 2005 September;28(9):2289-304.

6 . Wangberg SC. An internet-based diabetes self-care intervention tailored to self-efficacy. Health Educ Res 2008;23(1):170-9.

7. Martínez $P$, Moreno MG. Barreras ambientales para el apego al tratamiento en pacientes con diabetes tipo 2. Desarrollo Científico Enferm. 2006;14(6):196-201.

8. Whitemore R, Melkus GD, Grey M. Metabolic control, selfmanagement and psychosocial adjustment in women with type 2 diabetes. J Clin Nurs. 2005;14:195-203.

9. Ostrosky-Solís F, López-Arango G, Ardila A. Influencias de la edad y de la escolaridad en el examen breve del estado mental (Mini-mental State Examination) en una población hispanohablante. Rev Salud Menta.I 1999;22:20-5.

10. Jurado S, Villegas ME, Méndez L, Rodríguez F, Loperena $V$, Varela R. La estandarización del inventario de depresión de Beck para los residentes de la ciudad de México. Rev Salud Mental. 1998;21:26-31.

11. World Health Organization. Obesity: preventing and managing the global epidemic. Report of a WHO Consultation on Obesity. Geneva: World Health Organization; 1997.

12. Tootbert D, Glasgow R. Assessing diabetes self-management: The summary of diabetes self-care activities questionnaire. In: Bradley C, editor. Handbook of Psychology and Diabetes. UK: Hardwood Academic; 1994. p. 354-93.

13. Michigan Diabetes Research and Training. Diabetes Care Profile. Michigan: University of Michigan. 1998. [acceso en: 16 Agosto 2005]. Disponible en: http://www.med.umich.edu/ mdrtc/profs/documents/svi/dcp.pdf.
14. Executive Summary: Standards of medical care in diabetes2009. Diabetes Care 2009. January;32(1 Suppl):6-12.

15. American Hearth Association. Third Report of the National Cholesterol Education Program (USA) National cholesterol education program. National Heart, Lung and Blood Institute. National Institutes of Health; 2002. NIH Publication No. 025215. [acceso en: 24 Agosto 2009]. Disponible en: http://circ. ahajournals.org/cgi/reprint/106/25/3143.

16. Secretaría de Salud (MX). Reglamento de la Ley General de Salud en Materia de Investigación. 1987. [acceso en: 20 Enero 2009]. Disponible en: http://www.salud.gob.mx/unidades/cdi/ nom/compi/rlgsmis.html.

17. Sousa VD, Zauszniewski JA, Musil CM, Price PJ, Davis SA. Relationship among self-care agency, sel-efficacy, self-care and glycemic control. Res Theory Nurs Pract. 2005;19(3):217-30.

18. Dunning T, Manias E. Medication knowledge and selfmanagement by people with type 2 diabetes. Aust J Adv Nurs. 2005;23(1):7-14.

19. Marks DF, Murray M, Evans B, Willing C, Woodall C, Sykes C. Comida y hábitos alimenticios. En Marks DF, Murray M, Evans B, Willing C, Woodall C, Sykes C, editores. Psicología de la Salud. México (MX): Manual Moderno; 2008. p. 125-39.

20. Shamah-Levy T, Villalpando-Hernández S, Rivera-Dommarco JA; Editores. Resultados de nutrición de la ENSANUT 2006. Instituto Nacional de Salud Pública (MX): Cuernavaca; 2007.

21. Sigh R, Press M. Clinical care and delivery can we predict future improvement in glycaemic control?. Diabetic Med. 2008;25:170-3. Doi:10.1111/j.1464-5491.2007.02309.

22.Pace AE, Ochoa-Vigo K, Larcher MH, Morais AP. El conocimiento sobre diabetes mellitus en el proceso de autocuidado. Rev. Latino-Am. Enfermagem. 2006;14(5):713-9.

23. Gallegos EC, Ovalle-Berumen F, Gómez-Meza MV. Metabolic Control of adults with type 2 diabetes mellitus through education and counseling. J Nurs Scholarsh. 2006;38(4):344-51.

24. Rodrigo FFL, Zanetti ML, Santos MA, Martins TA, Sousa VD, Teixeira CRS. Knowledge and altitude: important components in diabetes education. Rev. Latino-Am. Enfermagem. 2009, jul/ ago 17(4)468-73.

25. Otero LM, Zanetti ML, Ogrizio MD. Knowledge of diabetic patients about their desease before afther implementig a diabetes education program. Rev. Latino-Am. Enfermagem. 2008, março/abril 16(2)231-7. 